\title{
Dynamic Pattern of Reg-2 Expression in Rat Sensory Neurons after Peripheral Nerve Injury
}

\author{
Sharon Averill, ${ }^{* *}$ Danny R. Davis, ${ }^{2 *}$ Peter J. Shortland, ${ }^{1}$ John V. Priestley, ${ }^{1}$ and Stephen P. Hunt ${ }^{2}$ \\ ${ }^{1}$ Department of Neuroscience, Queen Mary University of London, London, E1 4NS, United Kingdom, and 2Department of \\ Anatomy and Developmental Biology, University College London, London, WC1E 6BT, United Kingdom
}

\begin{abstract}
The $16 \mathrm{kDa}$ pancreatitis-associated protein Reg-2 has recently been shown to facilitate the regeneration of motor and sensory neurons after peripheral nerve injury in the adult rat. Reg-2 has also been shown to be a neurotrophic factor that is an essential intermediate in the pathways through which CNTF supports the survival of motor neurons during development. Here we report the dynamic expression of Reg-2 in rat sensory neurons after peripheral nerve injury. Reg-2 is normally not expressed by dorsal root ganglion (DRG) cells, but we show, using immunocytochemistry, that Reg-2 is rapidly upregulated in DRG cells after sciatic nerve transection and after $24 \mathrm{hr}$ recovery is expressed almost exclusively in small-diameter neurons that bind the lectin Griffonia simplicifolia IB4 and express the purinoceptor $\mathrm{P}_{2} \mathrm{X}_{3}$. However, by $7 \mathrm{~d}$ after axotomy, Reg-2 is expressed in medium to large neurons and coexists partly with the neu-
\end{abstract}

ropeptides galanin and neuropeptide $\mathrm{Y}$, which are also upregulated after peripheral nerve transection. At this time point, Reg-2 is no longer expressed in small neurons, and there is no colocalization with IB4 binding neurons, demonstrating a shift in Reg-2 expression from one subset of DRG neurons to another. We also show by double labeling for activating transcription factor 3, a transcription factor that is upregulated after nerve injury, that Reg-2 expression occurs predominantly in axotomized DRG cells but that a small percentage of uninjured DRG cells also upregulate Reg-2. The selective expression within IB4/P2X $X_{3}$ cells, and the dynamic shift from small to large cells, is unique among DRG peptides and suggests that Reg-2 has a distinctive role in the injury response.

Key words: regeneration; axotomy; dorsal root ganglia; neuropeptide; peripheral nerve injury; Reg-2
Reg-2 (also known as PAP1 in rat, $\operatorname{RegIII} \beta$ in mouse, and $\mathrm{HIP} / \mathrm{PAP}$ in humans) is a $16 \mathrm{kDa}$ secretory protein that has recently been shown to have proregenerative properties in motor and sensory neurons after peripheral nerve injury in the rat (Livesey et al., 1997). Reg-2 is massively upregulated in subsets of sensory neurons and in all regenerating $\alpha$ motor neurons after sciatic nerve injury (Livesey et al., 1997). In vitro, Reg-2 has a mitogenic effect on Schwann cells, and direct injection of Reg-2 antibody into the crushed nerve retarded the regeneration of the relevant subsets of sensory and motor neurons. These results strongly imply a novel principle: neurons do not simply grow passively through a permissive environment, but they can actively secrete factors that can change the environment through which they are regenerating. Reg-2 is also constitutively expressed in subpopulations of motor neurons during development, and this expression is driven by cytokines of the interleukin-6 (IL-6) family, which includes ciliary neurotrophic factor (CNTF), leukemia inhibitory factor (LIF), and cardiotrophin (CT-1) (Livesey et al., 1997). These cytokines have been shown to prevent motor neuron cell death that follows neonatal axotomy (Sendtner et al., 1990; Cheema et al., 1994; Pennica et al., 1996) and to prolong motor neuron survival in strains of mice that show spontaneous motor neuron cell death (Sendtner et al., 1992; Mitsumoto et al., 1994; Lindsay, 1996; Winter et al., 1996; Bordet et al., 1999).

\footnotetext{
Received July 26, 2001; revised April 29, 2002; accepted May 3, 2002

We gratefully acknowledge support from the European Commission (S.P.H.) and the Wellcome Trust (J.V.P.).

*S.A. and D.R.D. contributed equally to this study.

Correspondence should be addressed to Prof. John Priestley, Department of Neuroscience, Queen Mary University of London, Mile End Road, London, E1 4NS, United Kingdom. E-mail: j.v.priestley@qmul.ac.uk.

Copyright (ㄷ) 2002 Society for Neuroscience 0270-6474/02/227493-09\$15.00/0
}

More recently, Nishimune and colleagues (2000) have shown that during development Reg-2 is a neurotrophic factor that is an essential intermediate in the pathways through which CNTF supports the survival of motor neurons (Nishimune et al., 2000).

The role of Reg-2 expression in sensory neurons of the dorsal root ganglion (DRG) has yet to be elucidated but is clearly of interest because peripheral sensory neurons have the capacity to regenerate, and neuropoietic cytokines play a role in the maintenance of sensory neurons after peripheral nerve injury (Simon et al., 1995; Thompson et al., 1998; Thier et al., 1999). In a previous study (Livesey et al., 1997) Reg-2 was shown to be upregulated in a subpopulation of DRG cells after sciatic nerve crush, but the DRG cell type was not characterized. Here we have performed a detailed analysis of Reg-2 expression in lumbar DRG cells and their central projections at various time points after sciatic nerve crush and transection. Reg-2 expression is dynamic, appearing within distinct populations of sensory neurons at different times after axon damage.

\section{MATERIALS AND METHODS}

Materials and antibodies. All chemicals and materials were obtained from Sigma-Aldrich (Poole, UK) or Merck-BDH (Lutterworth, UK) unless stated otherwise. In this study, the following primary antibodies were used: anti-Reg-2 polyclonal antibody (Livesey et al., 1997) was raised in rabbit against whole recombinant protein and used in these studies at 1:20,000 for immunoperoxidase, 1:8,000 for indirect labeled immunofluorescence, and 1:120,000 with tyramide signal amplification (TSA; see below). Anti-trkA rabbit polyclonal antibody (Upstate Biotechnology, Lake Placid, NY) was used at 1:10,000 (TSA procedure); rabbit anti-neuropeptide Y (NPY) and anti-galanin antisera (both Affiniti, Exeter, UK) were used at 1:2,000, and guinea pig anti-P2X3 antiserum (Neuromics, Minneapolis, MN) was used at 1:1,500,000 (TSA procedure). Anti-activating transcription factor 3 (ATF3) rabbit polyclonal antibody (Santa Cruz, CA) was used at 1:200. Isolectin Griffonia simplicifolia IB4 FITC conjugate (Sigma-Aldrich, Dorset, UK) was used at a dilution of 1:1000. 


\begin{tabular}{|c|c|c|c|c|c|}
\hline Time point & Reg-2 & IB4 & $\operatorname{trkA}$ & GAL & ATF3 \\
\hline Control & $0.8 \pm 0.4$ & $49.7 \pm 2.0$ & $44.0 \pm 0.6$ & $8.7(2)$ & $0.8 \pm 0.4$ \\
\hline $24 \mathrm{hr}$ & $14.1 \pm 1.0$ & $44.3 \pm 2.4$ & $47.5 \pm 3.2$ & $22.5(2)$ & $72.9 \pm 4.4(5)$ \\
\hline $7 \mathrm{~d}$ & $10.0 \pm 1.5(4)$ & $35.5 \pm 0.4$ & $31.2 \pm 0.9$ & $40.4 \pm 3.2$ & $58.7 \pm 6.6$ \\
\hline $30 \mathrm{~d}$ & $10.9 \pm 0.5$ & $32.2 \pm 5.3$ & $39.0 \pm 3.2$ & $39.3 \pm 7.4$ & $67.0 \pm 5.0$ \\
\hline
\end{tabular}

The numbers shown are mean \pm SEM and are based on counts from three animals unless indicated otherwise.

Animals and surgery. For all experiments, male Sprague Dawley or Wistar rats of $\sim 150-200$ gm were used, and preliminary experiments revealed no difference in Reg- 2 expression, or upregulation, between these two strains. Unilateral sciatic nerve crush (15 Wistar, 4 Sprague Dawley) or transection (12 Wistar, 16 Sprague Dawley) was performed at mid-thigh level under deep anesthesia $[4 \%(\mathrm{v} / \mathrm{v})$ halothane for induction and maintained with $2 \%(\mathrm{v} / \mathrm{v})$ during surgery]. For transection the sciatic nerve was first ligated and then cut distal to the ligature. Animals were allowed to recover for $24 \mathrm{hr}, 5 \mathrm{~d}, 7 \mathrm{~d}, 30 \mathrm{~d}$, or 8 weeks, at which time tissue was removed for immunocytochemical analysis. In some experiments $(n=4)$, the sciatic nerve was injected with $5 \mu$ l of $5 \%(w / v)$ Fast Blue at the time of transection to retrogradely label the axtomized sciatic afferents. In six other animals, axonal transport was studied by ligating the L4/L5 lumbar dorsal roots and proximal portion of sciatic nerve (two animals) or by ligating the sciatic nerve (two animals) or saphenous nerve (two animals) at mid-thigh level $3 \mathrm{~d}$ before perfusion fixation.

Tissue processing. Rats were deeply anesthetized with pentobarbitone (60 $\mathrm{mg} / \mathrm{kg}$, i.p.) and transcardially perfused with $\sim 100 \mathrm{ml}$ sterile saline con-
Figure 1. Expression of Reg-2 in DRG after peripheral nerve injury. $A-D$ show Reg-2 immunoreactivity in ipsilateral $(A-C)$ and naïve control $(D)$ lumbar DRG $1 \mathrm{~d}(A), 7 \mathrm{~d}(B)$, and $30 \mathrm{~d}(C)$ after sciatic nerve transection. Reg-2 is upregulated after sciatic transection, but expression is dynamic, appearing predominantly in small cells at $1 \mathrm{~d}(A)$ but in medium and large cells at $7 \mathrm{~d}(B)$. $E-H$ show the disposition of Reg-2immunoreactive axons in an L4 ganglion $(D R G)$ with attached ventral root $(V R)$, dorsal root $(D R)$, and spinal nerve $(S N)$ at $1 \mathrm{~d}$ after sciatic transection. The labeling in $E$ shows the areas that were sampled for the highmagnification images in $F-H$. Immunoreactive axons (arrows) can be observed within and on the peripheral side of the ganglion $(F)$ as well as within the spinal nerve $(G)$. However, very few axons were present on the central side of the ganglion or within the attached dorsal root $(H)$ or ventral root. Scale bars: $A-D, 100 \mu \mathrm{m} ; E, 200 \mu \mathrm{m} ; F-H, 50 \mu \mathrm{m}$.
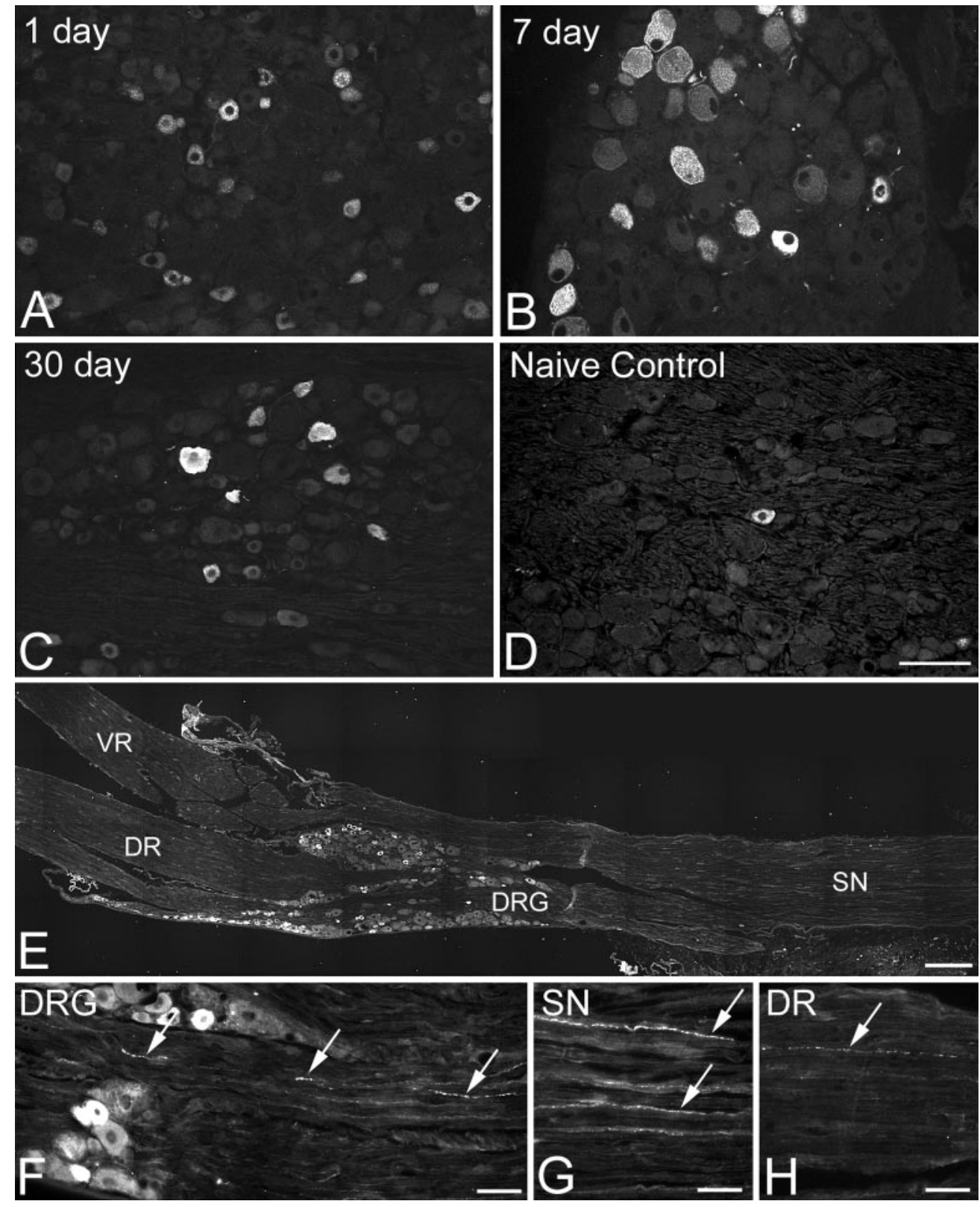


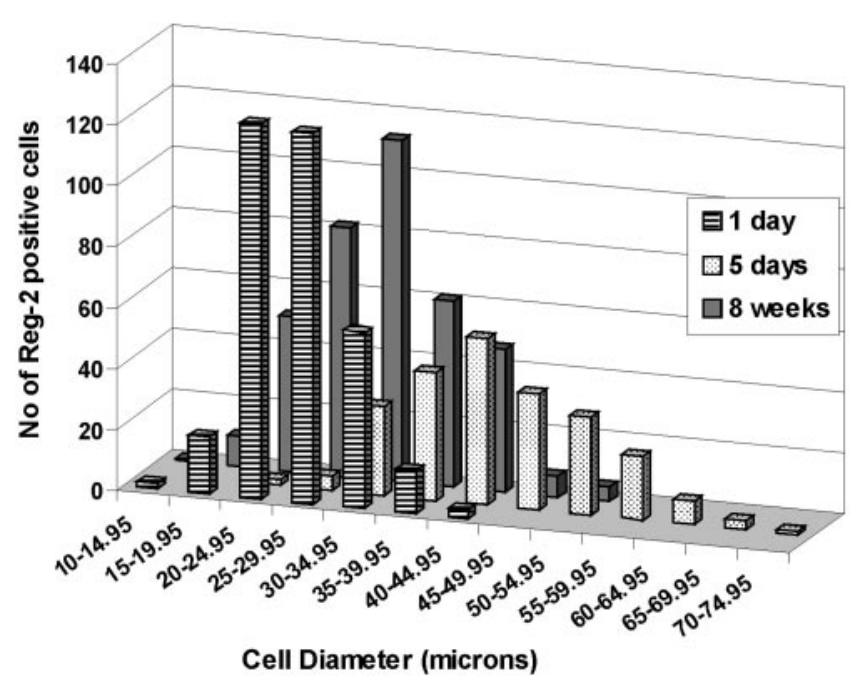

Figure 2. Size distribution of Reg-2-immunoreactive sensory neurons in L4/5 DRG after sciatic nerve transection. Note that at $24 \mathrm{hr}$ many small-diameter sensory neurons are immunoreactive, but by $5 \mathrm{~d}$ predominantly medium-diameter cells show Reg- 2 expression. At $5 \mathrm{~d}$ after transection, some neurons are large, as indicated by the long tail seen on the size distribution graph, which is not seen by 8 weeks after transection.

taining $5000 \mathrm{U} / 1$ heparin followed by $\sim 300 \mathrm{ml}$ of either $4 \%(\mathrm{w} / \mathrm{v})$ paraformaldehyde in $0.1 \mathrm{M}$ phosphate buffer, $\mathrm{pH} 7.4$ (PB), or PLP fixative composed of $2 \%(\mathrm{w} / \mathrm{v})$ paraformaldehyde, $100 \mu \mathrm{M}$ sodium metaperiodate, and $750 \mu \mathrm{M}$ L-lysine monhydrochloride in PB. Both ipsilateral and contralateral L4 and L5 lumbar DRGs, lumbar spinal cord, and lower medulla were dissected and postfixed for $2 \mathrm{hr}$ at $4^{\circ} \mathrm{C}$ and then transferred to $20-30 \%$ $(\mathrm{w} / \mathrm{v})$ sucrose in $0.1 \mathrm{~m} \mathrm{~PB}$ containing $0.02 \%(\mathrm{w} / \mathrm{v})$ sodium azide. Tissue was frozen on dry ice, and sectioning was performed on either a freezing microtome (Leica, Hemel Hempstead, UK) or a cryostat (Leica).

Microtome sections were cut at 20 or $40 \mu \mathrm{m}$ into $5 \%$ (w/v) sucrose in $0.1 \mathrm{M}$ PB containing $0.02 \%(\mathrm{w} / \mathrm{v})$ sodium azide and were processed for Reg-2 immunoreactivity as free-floating sections. Tissue for cryostat sectioning was embedded in OCT, cut at $6 \mu \mathrm{m}$, and thaw-mounted onto Superfrost plus microscope slides.

Immunocytochemistry. To determine localization of expression in the DRG for cell size distribution analysis, free-floating microtome sections were first rinsed in $0.1 \mathrm{M} \mathrm{PB}$, followed by a 30 min incubation in $0.1 \mathrm{M} \mathrm{PB}$ containing $0.6 \%(\mathrm{w} / \mathrm{v})$ hydrogen peroxide at room temperature to block any endogenous peroxidase activity. Sections were then transferred into $0.1 \mathrm{M}$ PB containing 3\% (v/v) normal goat serum, $0.25 \%(\mathrm{v} / \mathrm{v})$ Triton X-100, and $0.02 \%(\mathrm{w} / \mathrm{v})$ sodium azide (PBT) and incubated for $1 \mathrm{hr}$ at room temperature. For incubation in primary antibody, sections were transferred into fresh PBT containing Reg-2 polyclonal antiserum and incubated at $4^{\circ} \mathrm{C}$ for $2 \mathrm{~d}$. After washes in $0.1 \mathrm{M} \mathrm{PB}$, sections were incubated in biotinylated goat anti-rabbit IgG (Vector Laboratories, Peterborough, UK; 1:400 in PBT) for $1 \mathrm{hr}$ at room temperature. After further washes, sections were incubated in avidin-biotin complex (Vector Laboratories; 1:200 in 0.1 M PB) that had been premixed 30 min previously. Finally, sections were washed again in 0.1 M PB followed by a brief wash in $0.15 \mathrm{M}$ Tris- $\mathrm{HCl}, \mathrm{pH}$ 7.4. Sections were then transferred into $0.15 \mathrm{M}$ Tris- $\mathrm{HCl}, \mathrm{pH} 7.4$, containing $0.25 \mathrm{mg} / \mathrm{ml}$ diaminobenzidine, $2 \mathrm{mg} / \mathrm{ml}$ nickel sulfate, and $0.003 \%$ (w/v) hydrogen peroxide to induce color reaction. Tissue sections were washed in $0.1 \mathrm{M} \mathrm{PB}$ to stop the color development. Mounted sections were allowed to air-dry overnight. They were then dehydrated through increasing alcohol concentrations and placed in Histoclear. Slides were then coverslipped using DPX as mountant.

For double-labeling experiments, standard immunofluorescence procedures were used using either indirect labeled immunofluorescence or a TSA kit (NEN Life Science Products, Hounslow, UK (Averill et al., 1995; Michael et al., 1997). Incubations were performed at room temperature and consisted of $1 \mathrm{hr}$ in $10 \%(\mathrm{v} / \mathrm{v})$ normal serum followed by $18-36 \mathrm{hr}$ in each set of primary antisera and $3 \mathrm{hr}$ in the developing secondary antisera. The two sets of antisera were applied sequentially, and this normally involved Reg-2 TSA followed by indirect-labeled immunofluo-

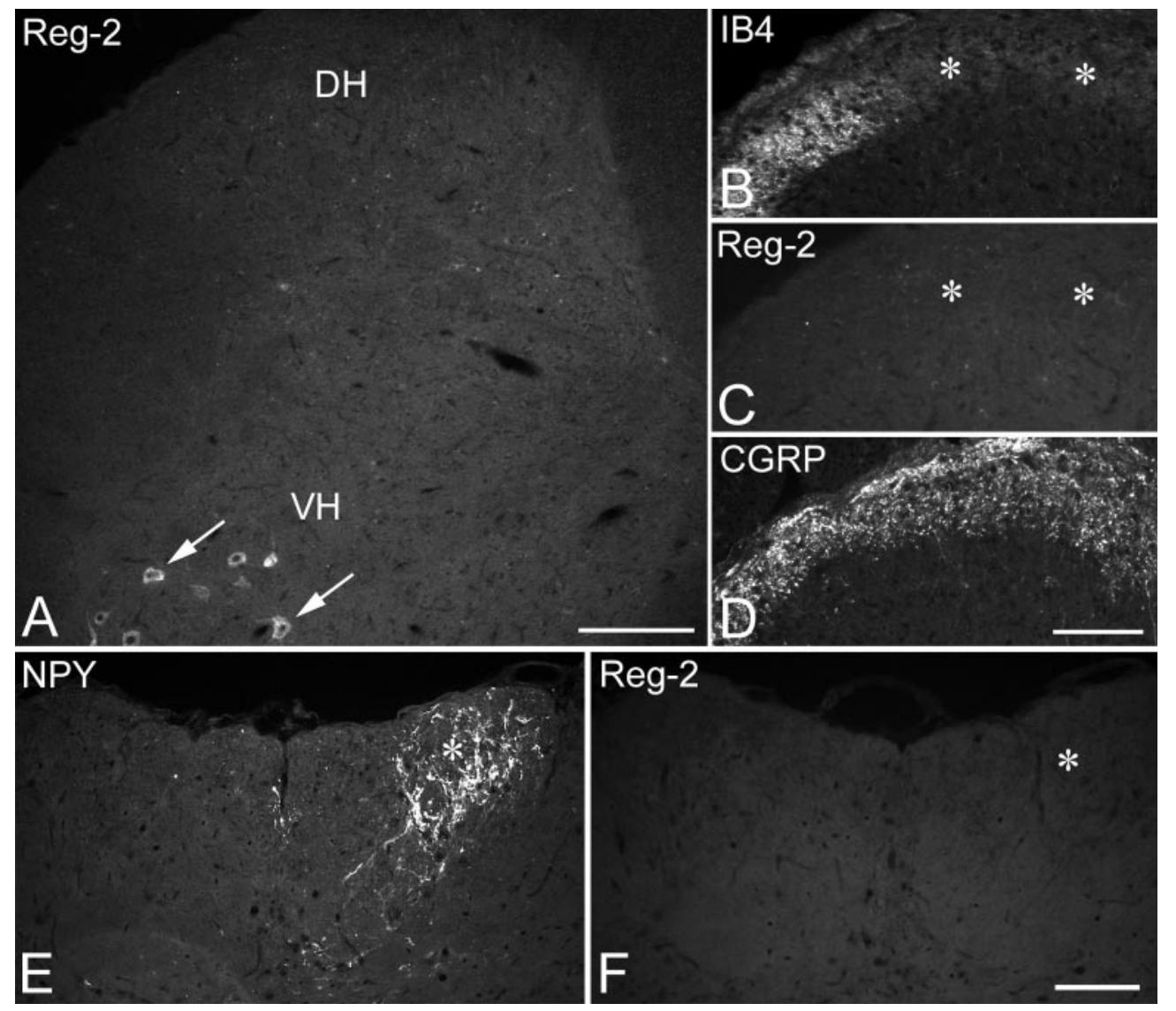

Figure 3. Analysis of Reg-2 immunoreactivity in the spinal cord and brain stem. $A-D$ show the lumbar spinal cord $7 \mathrm{~d}$ after sciatic nerve transection. Reg-2 immunoreactivity is expressed in the ventral horn $(V H)$ in axotomized motoneurons $(A$, arrows) but is absent from the dorsal horn $(D H)$, indicating that it is not present in the central terminals of axotomized primary afferents. $B-D$ show the superficial dorsal horn at high magnification, stained for IB4, Reg-2, or CGRP. Asterisks indicate the central terminal field of the axotomized sciatic nerve, which has downregulated IB4 (B). However, Reg-2 immunoreactivity in this region is not above background staining $(C)$, although CGRP staining confirms that primary afferent terminals are present $(D)$. $E$ and $F$ show the dorsal medulla $30 \mathrm{~d}$ after sciatic nerve transection. Ipsilateral to the transection, neuropeptide Y (NPY) immunoreactivity is upregulated within the gracile nucleus $(E)$ in the central terminal fields of the axotomized primary afferents (asterisk). However, there is no indication of Reg-2 immunoreactivity in that region $(F)$. Scale bars: $A, 200 \mu \mathrm{m} ; B-F$, $100 \mu \mathrm{m}$. 
rescence. Tetramethylrhodamine isothiocyanate (TRITC)-labeled antirabbit IgG was used for indirect immunofluorescence (Jackson ImmunoResearch, West Grove, PA; 1:400 dilution). TSA labeling was performed using biotinylated goat anti-rabbit IgG (1:400; Vector Laboratories) and Vectastain Elite peroxidase reagent (Vector Laboratories) followed by biotinyl tyramide (NEN Life Science Products, Hounslow, UK; TSA-indirect kit) and ExtrAvidin-FITC (1:500, Sigma-Aldrich, Dorset, UK). After incubation in secondary reagents, sections were washed briefly in PBS and then mounted in PBS/glycerol (1:3) containing $2.5 \%(\mathrm{w} / \mathrm{v})$ 1,4 diazobicyclo $(2,2,2)$ octane (DABCO; anti-fading agent). Controls for double labeling included reversing the order of the primary antisera, as well as omitting the first or second primary antiserum.

Image analysis. For cell size distribution and fast blue experiments, images were obtained using a Leica DMR microscope and either a JVC K Y-F50 color video camera (for DAB-labeled sections) or a Hamamatsu C5985 CCD camera (for immunofluorescence). Images were grabbed using VisionExplorer software, and cell diameters were measured using Leica Qwin (v2.2) image analysis software. For cell size distribution, we measured the diameters of Reg-2-positive cells from at least 16 sections taken from three animals at each time point. Only cells that displayed a distinct nucleus were measured. For immunofluorescence sections, quantitation of the proportion of Reg-2 expressing DRG cells was determined by counting the number of immunoreactive and non-immunoreactive neuronal profiles. In double-labeled sections, the percentage of Reg-2expressing cells expressing a second marker was assessed by switching between FITC and TRITC filter blocks. At least 250 labeled DRG cells were examined for each marker and counted on randomly chosen sections. Photographs were taken using a Hamamatsu C4742-95 digital camera, and plates were assembled using Adobe Photoshop.

\section{RESULTS}

Reg-2 immunoreactivity was assessed in rat lumbar DRG cells at various times after sciatic nerve injury. By $24 \mathrm{hr}$ after nerve transection, Reg-2 was expressed by $\sim 14 \%$ of DRG cells (Table 1). Immunoreactivity was observed in predominantly small diameter $(26.46 \mu \mathrm{m} \pm 4.65)$ sensory neurons, which appeared evenly distributed throughout the DRG (Figs. 1A, 2). By 5-7 d after sciatic nerve section, a similar percentage of DRG cells were stained, but the immunoreactivity was now observed in predominantly medium to large diameter $(44.47 \pm 8.98 \mu \mathrm{m})$ cells with some cells having very large diameters $(>60 \mu \mathrm{m})$ (Figs. 1B, 2). Immunoreactivity remained elevated at longer time points, but by 8 weeks the Reg-2-positive cells were predominantly of small to medium diameter with no very large cells observed (Fig. 2). Similar results were obtained with both nerve transection and crush at 1 and 7 d survival. Reg-2 immunoreactivity in contralateral lumbar DRG and in naïve control DRG was observed in just a few isolated profiles at each time point and omission of primary antisera resulted in a loss of immunoreactivity (not shown). In some material, light labeling of satellite glial cells was present (see Fig. 7C), but controls indicated that this was not specific. In addition to DRG cells, a few Reg-2-immunoreactive axons were visible within ganglia at all time points studied, and in wellstained preparations they could be observed running into and
Figure 4. Axonal transport of Reg-2. $A, C$, and $E$ show anterograde accumulation proximal to a L4/L5 dorsal root ligature, and $B, D$, and $F$ show anterograde accumulation proximal to a sciatic nerve ligature. Vertical arrows in $A$ and $B$ indicate the site of each ligature. CGRP shows a prominent accumulation in dorsal roots $(A)$ and in sciatic nerve $(B)$, whereas very little Reg-2 accumulation $(C, D$, arrows $)$ is seen in dorsal roots compared with sciatic nerve. IB4 staining proximal to the ligatures is not as prominent as CGRP but is present in both dorsal roots $(E)$ and sciatic nerve $(F)$. Scale bars: $A, C, E, 100 \mu \mathrm{m} ; B, D, F$, $200 \mu \mathrm{m}$.
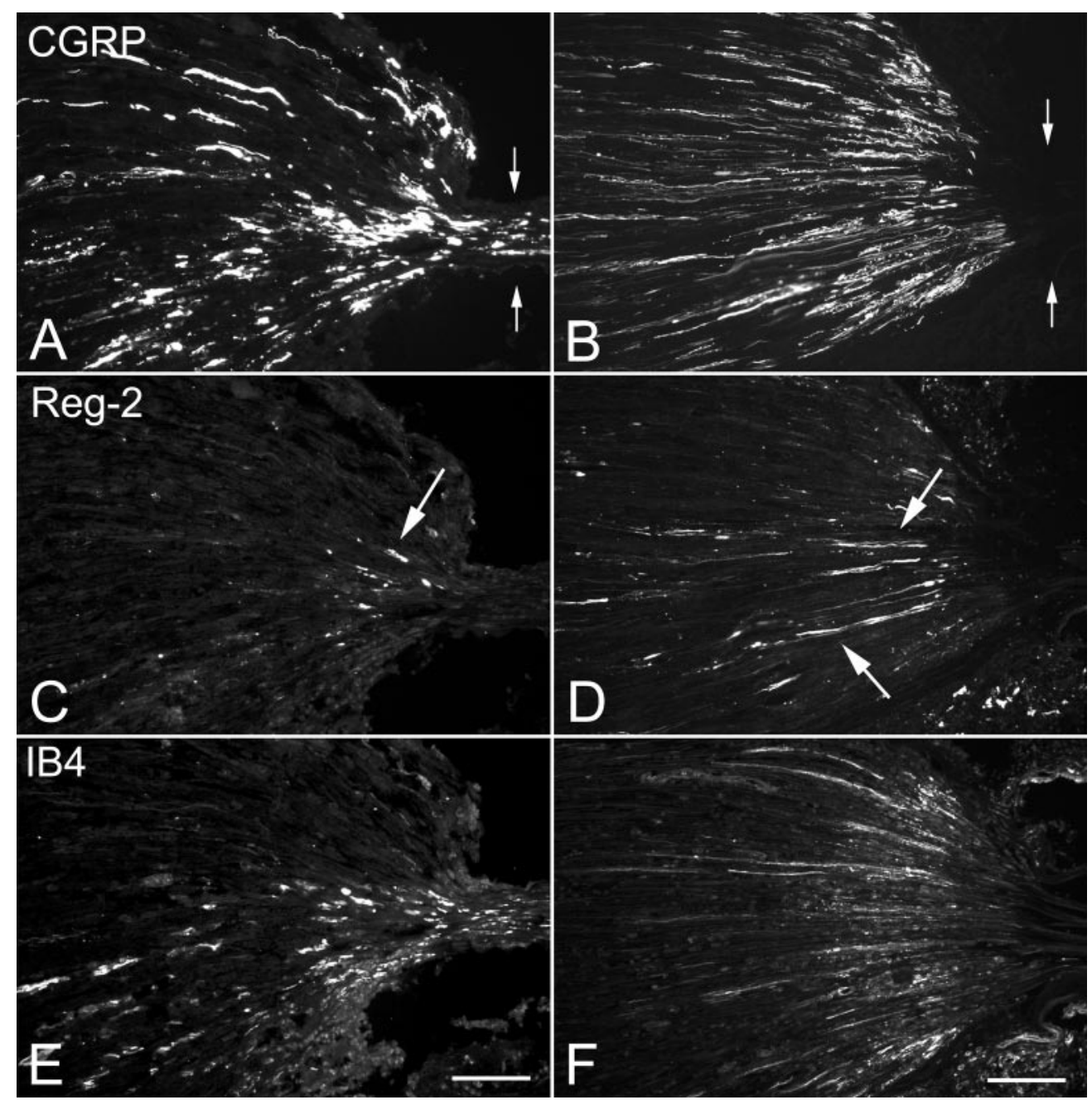

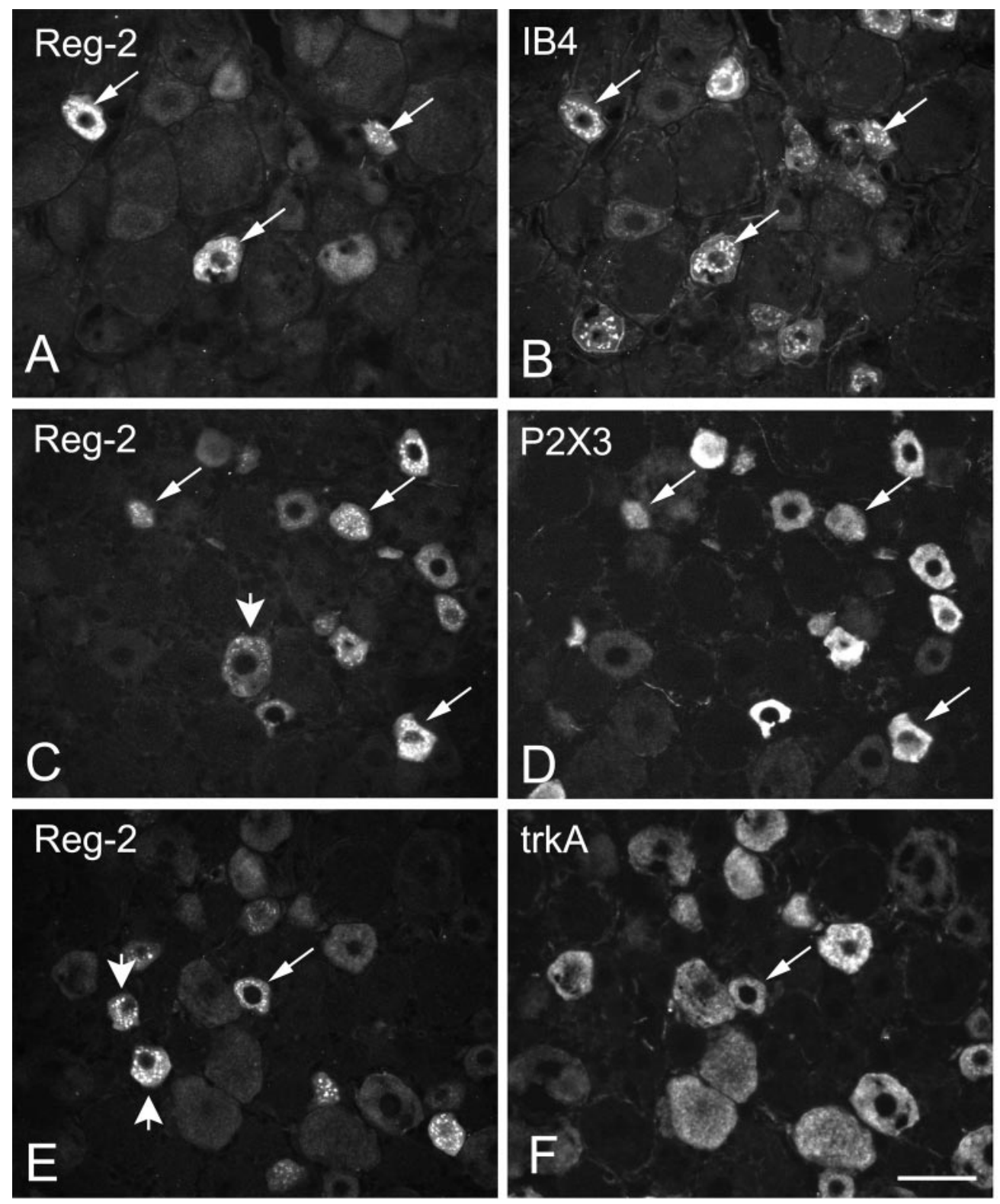

Figure 5. Colocalization of Reg-2positive cells $24 \mathrm{hr}$ after sciatic nerve transection. Immunofluorescent staining of single L5 DRG sections using Reg-2 $(A, C, E)$ and IB4-FITC conjugate $(B)$ or $\mathrm{P}_{2} \mathrm{X}_{3}(D)$ or trkA $(F)$ polyclonal antibodies $24 \mathrm{hr}$ after sciatic nerve transection. Arrows show doublelabeled cells, and arrowheads show Reg2-positive cells that are negative for the second marker. Note that many Reg-2positive cells show IB4 or P2X3 labeling. Scale bar, $50 \mu \mathrm{m}$.

within the spinal nerve (Fig. $1 E-G$ ). However, only a few immunoreactive axons were present within dorsal roots (Fig. $1 H$ ), which suggests that Reg-2 protein from DRG cells is transported peripherally but mainly not centrally after nerve injury. This conclusion was supported by analysis of the central termination territory of DRG axons and of the effect of nerve ligation. Immunostaining of lumbar spinal cord after sciatic nerve transection revealed the previously described expression of Reg-2 in motor neurons (Livesey et al., 1997) that remained only for the period of regeneration. Despite upregulation of Reg-2 in the DRG, as described above, no staining was observed in the dorsal horn of the spinal cord (Fig. $3 A-D$ ) or in the dorsal column nuclei (Fig. $3 E, F)$ at any time points studied (1, 7, and $30 \mathrm{~d}$ ). Accumulation of Reg-2 immunoreactivity was observed proximal to a ligature of the sciatic nerve (Fig. $4 B, D, F$ ) or saphenous nerve (a purely sensory nerve), but very little was present proximal to a dorsal root ligature (Fig. $4 A, C, E$ ).

The population of small-diameter Reg-2-positive neurons observed in L5 lumbar DRG $24 \mathrm{hr}$ after sciatic nerve injury coexists almost exclusively ( $>95 \%$ ) with IB4 binding and purinoreceptor $\mathrm{P}_{2} \mathrm{X}_{3}$ immunoreactivity (Fig. $5 A-D$, Table 2). IB4 binding and $\mathrm{P} 2 \mathrm{X}_{3}$ expression have been shown to coexist in that $\sim 98 \%$ of $\mathrm{P} 2 \mathrm{X}_{3}$-expressing sensory neurons are IB4-positive (Bradbury et al., 1998). At this same $24 \mathrm{hr}$ time point, a proportion of the L5 DRG Reg-2-positive profiles (21\% after transection and 25\% after nerve crush) also colabel for the nerve growth factor (NGF) receptor trkA (Fig. 5E, $F$ ). Numerous DRG cells showed galanin immunoreactivity, but there was little coexistence with Reg-2 (Table 2).

At $7 \mathrm{~d}$ after sciatic nerve injury (both transection and crush), Reg-2 coexpression with IB4 binding was much reduced (Fig. $6 A, B$, Table 2), but a large proportion of the Reg-2immunoreactive profiles showed immunoreactivity for galanin (Fig. 6C,D) and NPY (Fig. 6E,F). Both of these peptides have been shown to be upregulated in sensory neurons after sciatic nerve injury (Hokfelt et al., 1987; Villar et al., 1989; Wakisaka et 


\begin{tabular}{|c|c|c|c|}
\hline $\begin{array}{l}\text { Time } \\
\text { point }\end{array}$ & Markers & $\begin{array}{l}\% \text { of Reg-2- } \\
\text { expressing cells } \\
\text { that also express } \\
\text { the marker }\end{array}$ & $\begin{array}{l}\% \text { of marker- } \\
\text { expressing cells that } \\
\text { also express Reg-2 }\end{array}$ \\
\hline \multirow[t]{6}{*}{$24 \mathrm{hr}$} & Reg-2 and IB4 & $95.3 \pm 1.8$ & $20.3 \pm 3.3$ \\
\hline & Reg-2 and P2X3 & $94.7 \pm 1.9$ & $28.2 \pm 2.0$ \\
\hline & Reg-2 and trkA & $21.2 \pm 2.0$ & $5.0 \pm 0.2$ \\
\hline & Reg-2 and galanin & 2.2 & 1.3 \\
\hline & Reg-2 and NPY & NA & NA \\
\hline & Reg-2 and ATF3 & $77.8 \pm 1.8$ & $7.2 \pm 0.2$ \\
\hline \multirow[t]{6}{*}{$7 d$} & Reg-2 and IB4 & $3.2 \pm 1.6$ & $0.6 \pm 0.3$ \\
\hline & Reg-2 and P2X3 & $20.3 \pm 4.9$ & $3.2 \pm 1.3$ \\
\hline & Reg-2 and trkA & $0.7 \pm 0.7$ & $0.1 \pm 0.1$ \\
\hline & Reg-2 and galanin & $48.6 \pm 3.5$ & $9.4 \pm 1.2$ \\
\hline & Reg-2 and NPY & $76 \pm 1.7$ & $19.8 \pm 1.3$ \\
\hline & Reg-2 and ATF3 & $96.5 \pm 2.6$ & $7.0 \pm 1.0$ \\
\hline \multirow[t]{6}{*}{$30 \mathrm{~d}$} & Reg-2 and IB4 & $20.9 \pm 10.5$ & $4.9 \pm 2.6$ \\
\hline & Reg-2 and P2X3 & $24.7 \pm 12.5$ & $5.3 \pm 2.7$ \\
\hline & Reg-2 and trkA & $11.4 \pm 5.7$ & $2.5 \pm 1.3$ \\
\hline & Reg-2 and galanin & $53.8 \pm 11.8$ & $17.6 \pm 1.8$ \\
\hline & Reg-2 and NPY & $39.8 \pm 4.4$ & $10.6 \pm 0.8$ \\
\hline & Reg-2 and ATF3 & $71.8 \pm 9.5$ & $7.1 \pm 0.3$ \\
\hline
\end{tabular}

The numbers shown are mean \pm SEM and are based on counts from three animals, with the exception of the $24 \mathrm{hr}$ Reg- 2 and galanin counts, which are based on two animals. NA, Not applicable.

al., 1991, 1992; Ma and Bisby, 1997). At 30 d, coexistence with NPY and galanin was still present, and some coexistence with IB4 was again evident (Table 2).

To determine whether Reg-2 expression was restricted to the injured sensory neurons, we performed colabeling experiments for a transcription factor, ATF3, which has been shown to be a marker for injured DRG neurons (Tsujino et al., 2000). In a separate set of experiments, the neuronal tracer molecule Fast Blue $[5 \mu \mathrm{l}$ of $5 \%(\mathrm{w} / \mathrm{v})]$ was injected into the stump of the transected sciatic nerve to retrogradely label axotomized sciatic projecting neurons in L4/5 DRG. At all time points examined (1, 7, and $30 \mathrm{~d}$ ), we found a proportion of Reg-2-positive profiles that either were ATF3 negative (Fig. 7) or did not contain Fast Blue tracer (data not shown). Thus $59-73 \%$ of DRG cells showed ATF3 after sciatic transection (Table 1), and 72-97\% of Reg-2 cells showed ATF3 immunoreactivity (Table 2). We conclude that the population of Reg-2 positive, and ATF3- or Fast Bluenegative, neurons represent uninjured DRG neurons that have upregulated Reg-2.

\section{DISCUSSION}

This analysis of Reg-2 expression has uncovered a dynamic pattern of protein expression that has not been reported previously in the nervous system. We report here that after peripheral nerve injury, Reg-2 displays an initial phase ( $24 \mathrm{hr}$ ) of expression in small-diameter, predominantly nociceptive sensory neurons, but by $5 \mathrm{~d}$ expression has switched from these small-diameter neurons to a larger-diameter non-nociceptive population. This pattern of Reg-2 expression has a number of interesting features that make it quite unique and were not reported in the original study describing DRG expression (Livesey et al., 1997). First, Reg-2 is one of a very small number of molecules that are rapidly upregu- lated after nerve injury. Second, Reg-2 is the first example of a molecule that is selectively upregulated in the IB4/P2X 3 , GDNFsensitive population of nociceptors. Third, the shift in Reg-2 expression from initially small-diameter to subsequently largediameter neurons is unique and may reflect the selective expression of cytokines and growth factors adjacent to the site of damage or denervated target (see below). Fourth, Reg-2 is axonally transported predominantly peripherally and not centrally.

Reg-2 is a gene belonging to a larger family of Reg-related genes. The original member of the family, Reg, was a novel gene expressed in regenerating pancreatic islet cells (Terazono et al., 1988) and was found to code for a $16 \mathrm{kDa}$ secretory protein. In subsequent years, a family of related genes has been described under a rather varied nomenclature and been broadly categorized into three groups (for review, see Okamoto, 1999). Type I Reg proteins include the original Reg-1 protein and have been shown to have a role in promoting regeneration and proliferation of insulin-producing $\beta$-cells of pancreatic islets (Terazono et al., 1988, 1990; Zenilman et al., 1997; Levine et al., 2000). The type II Reg gene has been described only in the mouse (Unno et al., 1993), and the biological function of this gene has not been determined. Type III Reg proteins, which include rat Reg-2 described here, have been described as growth factors in liver cells (Christa et al., 1996), as possible anti-apoptotic agents in pancreatic acinar cells (Ortiz et al., 1998), and as a novel motor and sensory neuron survival factor (Livesey et al., 1997; Nishimune et al., 2000). In addition, a regenerative role of Reg-2 as a Schwann cell mitogen released at the regrowing axon tip has been described (Livesey et al., 1997).

Sensory neurons of the DRG can be categorized into subpopulations according to their size and expression of various neurochemical markers (for review, see Snider and McMahon, 1998; Hunt and Mantyh, 2001). Small-diameter sensory afferents represent $\sim 70 \%$ of the total lumbar DRG neuron population, have unmyelinated axons (C-fibers), and act mainly as nociceptors. The large-diameter afferents of the neuron population have myelinated axons (A $\beta$-fibers), innervate mechanoreceptors peripherally, and mediate proprioceptive and tactile responses. They can be immunocytochemically identified using antibodies that recognize high molecular weight neurofilament protein. Smalldiameter DRG neurons can be further characterized into a peptide-expressing [such as calcitonin-related gene product (CGRP) and substance P] and NGF-responsive subset and a nonpeptidergic, GDNF-responsive subset that bind isolectin-B4 (IB4) and express the purinoreceptor P2X $\mathrm{X}_{3}$ (Averill et al., 1995; Bennett et al., 1998; Priestley et al., 2002).

Peripheral nerve injury induces dramatic changes in gene expression in DRG neurons. For instance, after peripheral nerve transection or crush, the transcription factors c-jun (Herdegen et al., 1992; Jenkins et al., 1993) and ATF3 (Tsujino et al., 2000) are expressed in all injured neurons within $24 \mathrm{hr}$, whereas the pattern and extent of the expression of neuropeptides such as galanin and NPY are dependent on the time after injury (Hokfelt et al., 1987; Wakisaka et al., 1991; Zhang et al., 1998; Landry et al., 2000). Endogenous expression of these peptides in normal sensory neurons is limited to a small number $(<5 \%)$ of small-diameter cells, but after injury expression is robustly enhanced and maintained in neurons of all sizes.

Reg-2 expression is rarely seen in control ganglia, but both mRNA (Livesey et al., 1997) and protein (this study) are upregulated after nerve injury. Twenty-four hours after either sciatic nerve transection or crush, Reg- 2 is transiently expressed within 

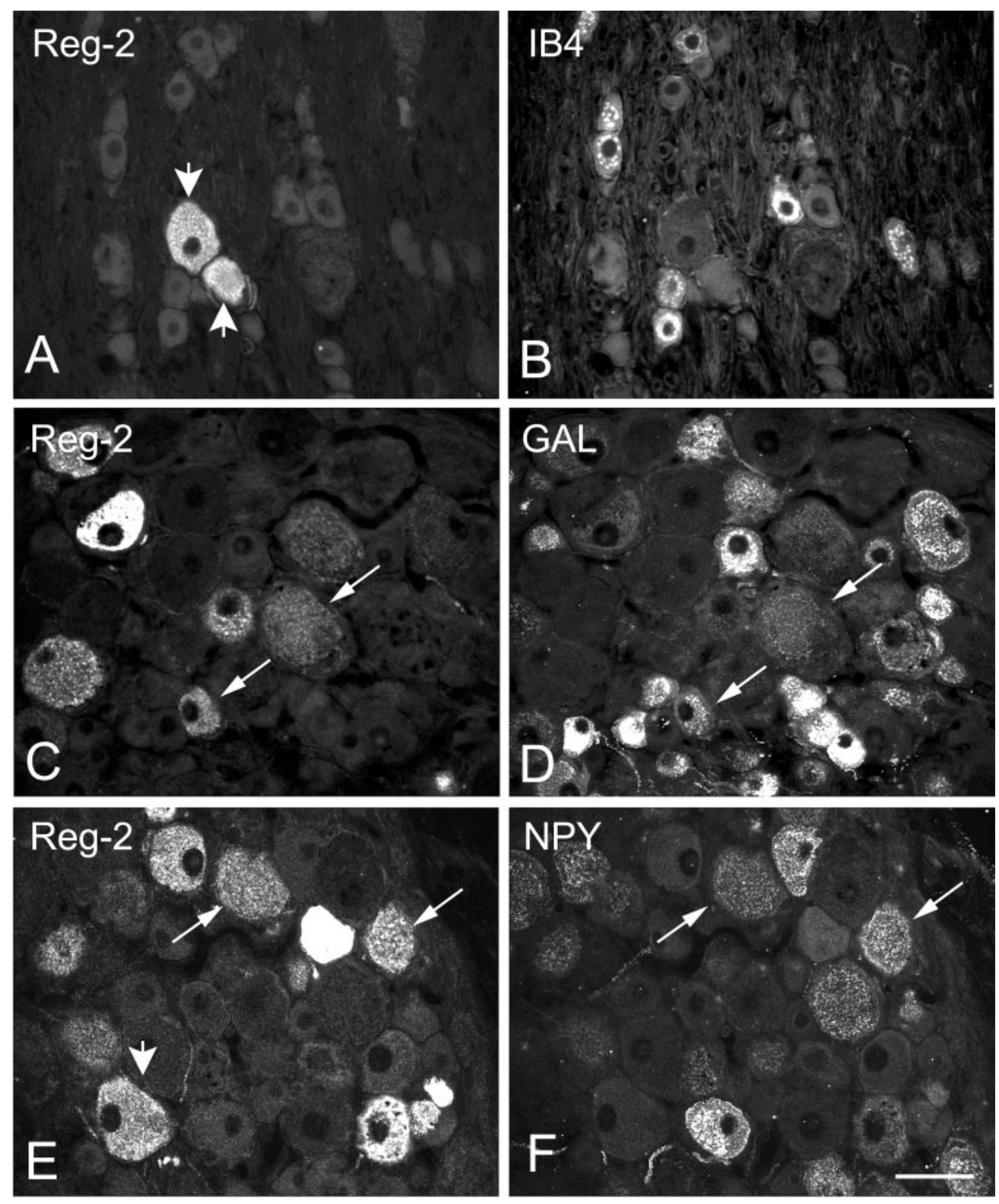

Figure 6. Colocalization of Reg-2positive cells $7 \mathrm{~d}$ after sciatic nerve transection. Immunofluorescent staining of single L4/5 DRG sections using antiReg-2 polyclonal antibody $(A, C, E)$ and IB4-FITC conjugate $(B)$ or galanin $(D)$ or NPY $(F)$ polyclonal antibodies, $7 \mathrm{~d}$ after sciatic nerve transection. Arrows show double-labeled cells, and arrowheads show Reg-2-positive cells that are negative for the second marker. Note that many Reg-2-positive cells at this time point show colocalization with NPY and galanin but not IB4. Scale bar, $50 \mu \mathrm{m}$. a subpopulation of the purinoreceptor $\mathrm{P}_{2} \mathrm{X}_{3}$ - expressing, GDNFsensitive, small-diameter sensory neurons. At this time point, all Reg-2-expressing cells show IB4 labeling, and the small percentage $(20 \%)$ that show trkA labeling is consistent with the reported overlap between IB4 and trkA (Averill et al., 1995). Many molecules are downregulated after peripheral nerve injury, and the rapid upregulation that we have observed for Reg-2 has so far been reported only for galanin and for the transcription factors c-jun and ATF3. In addition, most molecules that are upregulated are expressed in either the small trkA-expressing cells or largediameter neurons. Reg-2 is the only molecule, to date, that is selectively upregulated in the IB4-labeled, GDNF-sensitive population of cells. However, at longer time points, Reg-2 expression was restricted to medium- to large-diameter sensory neurons, although some expression in small neurons was observed at $30 \mathrm{~d}$. Our double-labeling studies, cell size distribution data, and counts of total percentage of DRG cells that express Reg-2 all suggest that this change is caused by a shift in Reg- 2 expression from the small- to medium/large-diameter neurons. This shift in
Reg-2 expression is very unusual. Galanin, for example, is expressed in medium- and large-diameter neurons at longer time points but continues to be expressed in small-diameter neurons. After peripheral nerve axotomy, brain-derived neurotrophic factor (BDNF) expression is also upregulated in medium- to largediameter sensory neurons (Cho et al., 1998; Michael et al., 1999), but this is the only cell group that shows upregulation. BDNF expression in small cells has been reported either to be downregulated (Cho et al., 1998) or to show no significant change (Michael et al., 1999). In addition, unlike Reg-2, crush injury can induce an increased expression of BDNF in all cell sizes (Cho et al., 1998). The pattern of expression seen for Reg-2 is thus unlike any other peptide, and because similar changes are seen after both transection and crush, it is likely that similar mechanisms for Reg-2 upregulation are activated in both injury models.

The dynamic changes in Reg-2 expression that we have observed may indicate that quite different factors control Reg-2 expression, and function, in the small and large DRG cells. For example, Reg-2 expression in the small-diameter IB4 cells may 

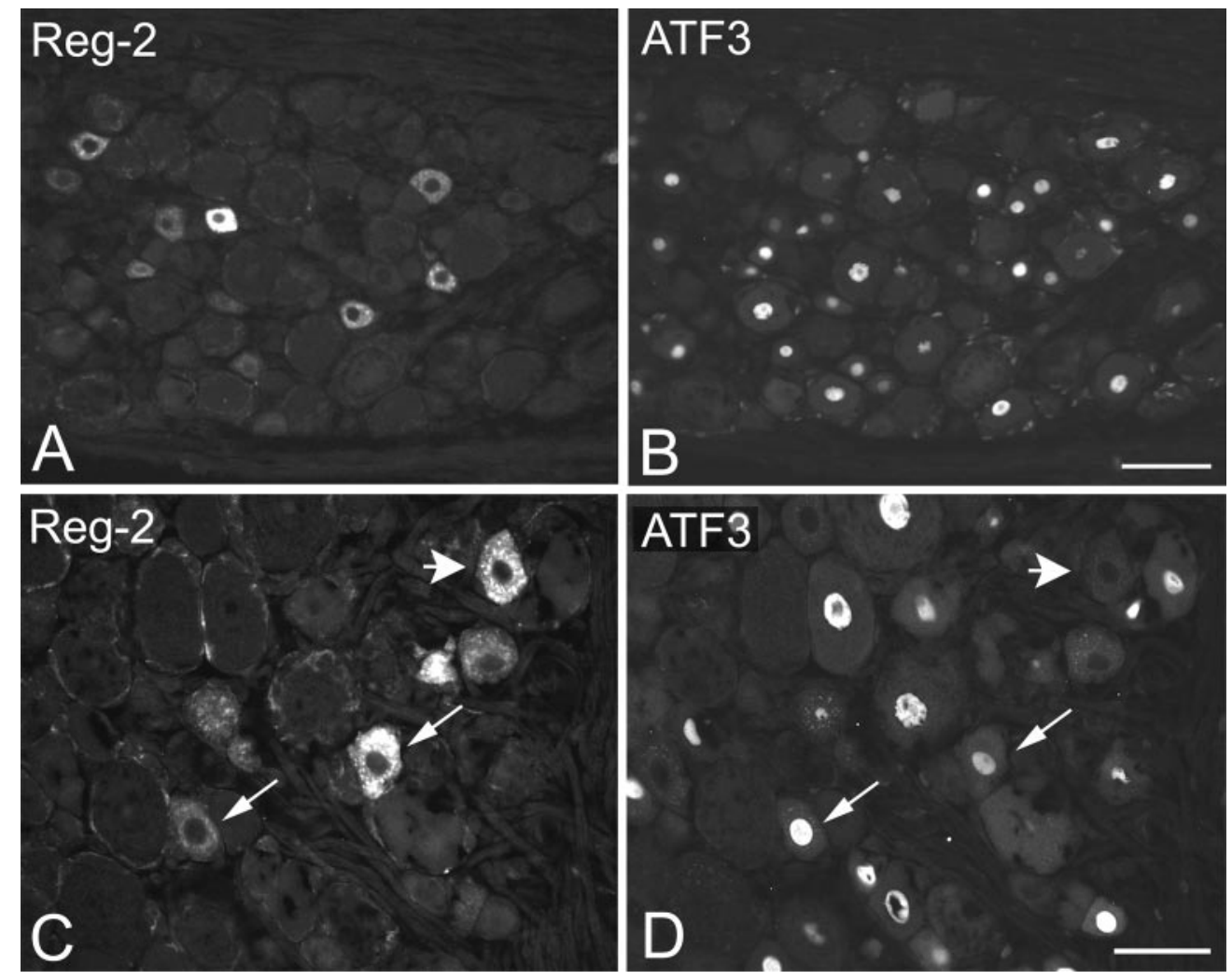

Figure 7. Colocalization of Reg-2positive profiles with axotomized sciatic projecting neurons. Immunofluorescent staining of single L5 DRG sections using Reg-2 $(A, C)$ and ATF3 $(B, D)$ polyclonal antibodies $24 \mathrm{hr}$ after sciatic nerve transection is shown. Arrows in $C$ and $D$ show profiles that are double labeled for Reg-2 and ATF3. Note that after axotomy, a small number of Reg2-positive profiles do not colocalize with the injured nerve marker ATF3 (arrowheads). Scale bars, $50 \mu \mathrm{m}$.

have local functions. The transient expression of Reg-2 may result in the delivery of a bolus of the peptide to the site of injury, or Reg- 2 could be released within the DRG itself and act on satellite glia and other neurons. This could account for the appearance of Reg-2 in neurons that were not axotomized in our experiments, as well as the lack of transport of the peptide into the dorsal horn. It has generally been observed that peptides, such as NPY, that are upregulated within the DRG are exported through the central axonal processes of the DRG to the dorsal horn and/or dorsal column nuclei. However, our studies indicate that Reg-2 is transported predominantly peripherally. A similar lack of central transport has recently been reported for the degenerin/epithelial sodium channel (DEG/ENaC) family member $\mathrm{BNaC} 1 \alpha$ (GarciaAnoveros et al., 2001). A local role for Reg-2 would be consistent with developmental studies in which Reg-2 appears to act in an autocrine/paracrine manner. After induction by a peripheral factor (possibly a cytokine of the LIF/CNTF family), Reg-2 can act on the parent cell or neighboring cells as an obligatory survival factor (Nishimune et al., 2000). The factor inducing Reg-2 in IB4 cells is not known but could be a member of the LIF/IL-6/CNTF family because IB4 cells are known to have binding sites for this family (Thompson et al., 1997). Whether locally released Reg-2 is responsible for its induction in large neurons is not known but worth further investigation. Such a role for the IB4 group of small-diameter neurons would also complement that of the peptidergic, small-diameter, NGF-responsive sensory fibers that have a well established role in the peripheral inflammatory response (McMahon, 1996).

Reg-2 expression in medium- to large-diameter sensory neurons $7 \mathrm{~d}$ after sciatic nerve section predominantly colocalized with NPY or galanin. The expression of these neuropeptides in uninjured DRG neurons is maintained at a low level, and it is thought that the upregulation in the same neurons after periph- eral nerve injury enables a change in function of sensory neurons from one of transduction of peripheral sensory information to one of survival and regeneration of the damaged neuron. The tonic release of Reg-2 from the extending growth cones of damaged large-diameter sensory neurons may serve a similar function. It has previously been shown that neutralizing Reg-2 activity at the site of peripheral nerve damage leads to a reduced level of regeneration (Livesey et al., 1997). This may have been an indirect effect, given that Reg-2 has a mitogenic effect on Schwann cells, which are crucial for the regenerative process.

In summary, we suggest that Reg-2 expression after injury may have an important role in the regenerative process, with distinct functions in small- and large-diameter cells. Reg- 2 may act both locally, after release within the ganglion, and at a distance at the site of nerve damage and regeneration.

\section{REFERENCES}

Averill S, McMahon SB, Clary DO, Reichardt LF, Priestley JV (1995) Immunocytochemical localization of trkA receptors in chemically identified subgroups of adult rat sensory neurons. Eur J Neurosci 7:1484-1494.

Bennett DL, Michael GJ, Ramachandran N, Munson JB, Averill S, Yan Q, McMahon SB, Priestley JV (1998) A distinct subgroup of small DRG cells express GDNF receptor components and GDNF is protective for these neurons after nerve injury. J Neurosci 18:3059-3072.

Bordet T, Schmalbruch H, Pettmann B, Hagege A, Castelnau-Ptakhine L, Kahn A, Haase G (1999) Adenoviral cardiotrophin-1 gene transfer protects pmn mice from progressive motor neuronopathy. J Clin Invest 104:1077-1085.

Bradbury EJ, Burnstock G, McMahon SB (1998) The expression of P2X3 purinoreceptors in sensory neurons: effects of axotomy and glial-derived neurotrophic factor. Mol Cell Neurosci 12:256-268.

Cheema SS, Richards LJ, Murphy M, Bartlett PF (1994) Leukaemia inhibitory factor rescues motoneurones from axotomy-induced cell death. NeuroReport 5:989-992.

Cho HJ, Kim JK, Park HC, Kim JK, Kim DS, Ha SO, Hong HS (1998) Changes in brain-derived neurotrophic factor immunoreactivity in rat dorsal root ganglia, spinal cord, and gracile nuclei following cut or crush injuries. Exp Neurol 154:224-230. 
Christa L, Carnot F, Simon MT, Levavasseur F, Stinnakre MG, Lasserre C, Thepot D, Clement B, Devinoy E, Brechot C (1996) HIP/PAP is an adhesive protein expressed in hepatocarcinoma, normal Paneth, and pancreatic cells. Am J Physiol 271:G993-1002.

Garcia-Anoveros J, Samad TA, Woolf CJ, Corey DP (2001) Transport and localization of the $\mathrm{DEG} / \mathrm{ENaC}$ ion channel BNaC1alpha to peripheral mechanosensory terminals of dorsal root ganglia neurons. J Neurosci 21:2678-2686.

Herdegen T, Fiallos-Estrada CE, Schmid W, Bravo R, Zimmermann M (1992) The transcription factors c-JUN, JUN D and CREB, but not FOS and KROX-24, are differentially regulated in axotomized neurons following transection of rat sciatic nerve. Mol Brain Res 14:155-165.

Hokfelt T, Wiesenfeld-Hallin Z, Villar M, Melander T (1987) Increase of galanin-like immunoreactivity in rat dorsal root ganglion cells after peripheral axotomy. Neurosci Lett 83:217-220.

Hunt SP, Mantyh PW (2001) The molecular dynamics of pain control. Nat Rev Neurosci 2:83-91.

Jenkins R, McMahon SB, Bond AB, Hunt SP (1993) Expression of c-Jun as a response to dorsal root and peripheral nerve section in damaged and adjacent intact primary sensory neurons in the rat. Eur J Neurosci 5:751-759.

Landry M, Holmberg K, Zhang X, Hokfelt T (2000) Effect of axotomy on expression of NPY, galanin, and NPY Y1 and Y2 receptors in dorsal root ganglia and the superior cervical ganglion studied with doublelabeling in situ hybridization and immunohistochemistry. Exp Neurol 162:361-384

Levine JL, Patel KJ, Zheng Q, Shuldiner AR, Zenilman ME (2000) A recombinant rat regenerating protein is mitogenic to pancreatic derived cells. J Surg Res 89:60-65.

Lindsay RM (1996) Therapeutic potential of the neurotrophins and neurotrophin-CNTF combinations in peripheral neuropathies and motor neuron diseases. Ciba Found Symp 196:39-48.

Livesey FJ, O’Brien JA, Li M, Smith AG, Murphy LJ, Hunt SP (1997) A Schwann cell mitogen accompanying regeneration of motor neurons. Nature 390:614-618.

Ma W, Bisby MA (1997) Differential expression of galanin immunoreactivities in the primary sensory neurons following partial and complete sciatic nerve injuries. Neuroscience 79:1183-1195.

McMahon SB (1996) NGF as a mediator of inflammatory pain. Philos Trans R Soc Lond B Biol Sci 351:431-440.

Michael GJ, Averill S, Nitkunan A, Rattray M, Bennett DL, Yan Q, Priestley JV (1997) Nerve growth factor treatment increases brainderived neurotrophic factor selectively in TrkA-expressing dorsal root ganglion cells and in their central terminations within the spinal cord. J Neurosci 17:8476-8490.

Michael GJ, Averill S, Shortland PJ, Yan Q, Priestley JV (1999) Axotomy results in major changes in BDNF expression by dorsal root ganglion cells: BDNF expression in large trkB and trkC cells, in pericellular baskets, and in projections to deep dorsal horn and dorsal column nuclei. Eur J Neurosci 11:3539-3551.

Mitsumoto H, Ikeda K, Klinkosz B, Cedarbaum JM, Wong V, Lindsay RM (1994) Arrest of motor neuron disease in wobbler mice cotreated with CNTF and BDNF. Science 265:1107-1110.

Nishimune H, Vasseur S, Wiese S, Birling MC, Holtmann B, Sendtner M, Iovanna JL, Henderson CE (2000) Reg-2 is a motoneuron neurotrophic factor and a signalling intermediate in the CNTF survival pathway. Nat Cell Biol 2:906-914.

Okamoto H (1999) The Reg gene family and Reg proteins: with special attention to the regeneration of pancreatic beta-cells. J Hepatobiliary Pancreat Surg 6:254-262.

Ortiz EM, Dusetti NJ, Vasseur S, Malka D, Bodeker H, Dagorn JC, Iovanna JL (1998) The pancreatitis-associated protein is induced by free radicals in AR4-2J cells and confers cell resistance to apoptosis. Gastroenterology 114:808-816.

Pennica D, Arce V, Swanson TA, Vejsada R, Pollock RA, Armanini M, Dudley K, Phillips HS, Rosenthal A, Kato AC, Henderson CE (1996)
Cardiotrophin-1, a cytokine present in embryonic muscle, supports long-term survival of spinal motoneurons. Neuron 17:63-74.

Priestley JV, Michael GJ, Averill S, Liu M, Willmott N (2002) Regulation of nociceptive neurons by NGF and GDNF. Can J Physiol Pharmacol 80:495-505.

Sendtner M, Kreutzberg GW, Thoenen H (1990) Ciliary neurotrophic factor prevents the degeneration of motor neurons after axotomy. Nature 345:440-441.

Sendtner M, Schmalbruch H, Stockli KA, Carroll P, Kreutzberg GW Thoenen H (1992) Ciliary neurotrophic factor prevents degeneration of motor neurons in mouse mutant progressive motor neuronopathy. Nature 358:502-504.

Simon R, Thier M, Kruttgen A, Rose-John S, Weiergraber O, Heinrich PC, Schroder JM, Weis J (1995) Human CNTF and related cytokines: effects on DRG neurone survival. NeuroReport 7:153-157.

Snider WD, McMahon SB (1998) Tackling pain at the source: new ideas about nociceptors. Neuron 20:629-632.

Terazono K, Yamamoto H, Takasawa S, Shiga K, Yonemura Y, Tochino Y, Okamoto H (1988) A novel gene activated in regenerating islets. J Biol Chem 263:2111-2114.

Terazono K, Uchiyama Y, Ide M, Watanabe T, Yonekura H, Yamamoto $\mathrm{H}$, Okamoto $\mathrm{H}$ (1990) Expression of reg protein in rat regenerating islets and its colocalization with insulin in the beta cell secretory granules. Diabetologia 33:250-252.

Thier M, Marz P, Otten U, Weis J, Rose-John S (1999) Interleukin-6 (IL-6) and its soluble receptor support survival of sensory neurons. J Neurosci Res 55:411-422.

Thompson SW, Vernallis AB, Heath JK, Priestley JV (1997) Leukaemia inhibitory factor is retrogradely transported by a distinct population of adult rat sensory neurons: colocalization with trkA and other neurochemical markers. Eur J Neurosci 9:1244-1251.

Thompson SW, Priestley JV, Southall A (1998) gp130 cytokines, leukemia inhibitory factor and interleukin-6 induce neuropeptide expression in intact adult rat sensory neurons in vivo: time-course, specificity and comparison with sciatic nerve axotomy. Neuroscience 84:1247-1255.

Tsujino H, Kondo E, Fukuoka T, Dai Y, Tokunaga A, Miki K, Yonenobu K, Ochi T, Noguchi K (2000) Activating transcription factor 3 (ATF3) induction by axotomy in sensory and motoneurons: a novel neuronal marker of nerve injury. Mol Cell Neurosci 15:170-182.

Unno M, Yonekura H, Nakagawara K, Watanabe T, Miyashita H, Moriizumi S, Okamoto H, Itoh T, Teraoka H (1993) Structure, chromosomal localization, and expression of mouse reg genes, reg I and reg II. A novel type of reg gene, reg II, exists in the mouse genome. J Biol Chem 268:15974-15982.

Villar MJ, Cortes R, Theodorsson E, Wiesenfeld-Hallin Z, Schalling M, Fahrenkrug J, Emson PC, Hokfelt T (1989) Neuropeptide expression in rat dorsal root ganglion cells and spinal cord after peripheral nerve injury with special reference to galanin. Neuroscience 33:587-604.

Wakisaka S, Kajander KC, Bennett GJ (1991) Increased neuropeptide Y (NPY)-like immunoreactivity in rat sensory neurons following peripheral axotomy. Neurosci Lett 124:200-203.

Wakisaka S, Kajander KC, Bennett GJ (1992) Effects of peripheral nerve injuries and tissue inflammation on the levels of neuropeptide Y-like immunoreactivity in rat primary afferent neurons. Brain Res 598:349-352.

Winter CG, Saotome Y, Saotome I, Hirsh D (1996) CNTF overproduction hastens onset of symptoms in motor neuron degeneration (mnd) mice. J Neurobiol 31:370-378.

Zenilman ME, Magnuson TH, Perfetti R, Chen J, Shuldiner AR (1997) Pancreatic reg gene expression is inhibited during cellular differentiation. Ann Surg 225:327-332.

Zhang X, Xu ZO, Shi TJ, Landry M, Holmberg K, Ju G, Tong YG, Bao L, Cheng XP, Wiesenfeld-Hallin Z, Lozano A, Dostrovsky J, Hokfelt $\mathrm{T}$ (1998) Regulation of expression of galanin and galanin receptors in dorsal root ganglia and spinal cord after axotomy and inflammation. Ann NY Acad Sci 863:402-413. 